\title{
Experimental Investigation on Fly Ash Bricks Incorporating M-Sand and GGBS
}

\author{
Dr.R.Kumutha ${ }^{1 *}$, Dr.K.Vijai ${ }^{2}$, S.Noor Nasifa ${ }^{3}$, M.Nivedhidha ${ }^{3}$ and R.Mukila Preethi $^{3}$ \\ ${ }^{1}$ Dean \& Head, Department of Civil Engineering, Sethu Institute of Technology, TN, India \\ ${ }^{2}$ Professor\& PG Head, Department of Civil Engineering, Sethu Institute of Technology, TN, India \\ ${ }^{3}$ Undergraduate students, Department of Civil Engineering, Sethu Institute of Technology, TN, India \\ *Corresponding Author: Dr.R.Kumutha, Department of Civil Engineering, Sethu Institute of Technology, \\ TN, India
}

\begin{abstract}
Bricks are a commonly used building material all over the world for constructing walls, pavement and other elements in masonry construction. Conventional bricks are manufactured by firing of clay in high temperature kilns. Extensive research is going on production of bricks from industrial wastes as there is a shortage of natural resources that are used as raw materials for the manufacturing of bricks. This paper presents an experimental study carried out on bricks made from fly ash, Ground Granulated Blast furnace Slag (GGBS) and Manufactured Sand (M-sand). This investigation also aims to use waste materials effectively since fly ash is a waste obtained from thermal power plants and GGBS is a waste from steel plant. The properties of the fly ash bricks are investigated by conducting various tests like Compressive strength test, water absorption test and test for dimensional tolerance as per relevant Indian Standards.
\end{abstract}

Keywords: Bricks; Fly ash; GGBS; M-sand; Compressive strength; Water absorption

\section{INTRODUCTION}

Bricks are used to construct walls, pavements and other elements in masonry construction. A brick is normally composed of soil consisting of clay, sand, lime, or concrete materials. Bricks are produced in different sizes, using different materials and of various classes. Large quantities of fly ash are available in and around thermal power stations all over India. The demand of bricks could be met by establishing small brick manufacturing units near thermal power plants in order to meet the local demand with less transportation costs. Fly ash bricks are normally made using class $\mathrm{C}$ or class $\mathrm{F}$ fly ash. Because of presence of large concentrations of calcium oxide in class $\mathrm{C}$ fly ash, the fly ash brick produced with Class $\mathrm{C}$ fly ash is generally self-cementing. When compared with clay bricks, fly ash bricks are lighter and stronger. Main ingredients of fly ash bricks are fly ash, water, quicklime, cement, aluminum powder and gypsum. Due to its outstanding engineering property and durability ,the fly ash brick widens its scope for application in developing infrastructure, building construction, construction of pavements, dams, tanks, irrigation works, canal lining and under water works etc.

On the other hand, due to rapid developments in infrastructure, the demand for natural river sand has increased tremendously thereby causing deficiency in most part of the world. Manufactured sand (MSand) is a substitute of river sand for producing concrete and it is produced by crushing of hard granite stone. The use of manufactured sand has been enlarged nowadays, due to the depletion of river sand for the use of construction. Other reasons for usage of M-Sand are its availability and the transportation cost. M-sand can be widely used in the manufacturing of bricks. Lot of researches has been done in the past in exploring various materials for the production of bricks.

Sunil Kumar conducted a feasibility study on the production of fly ash-lime-gypsum bricks and hollow blocks to solve the problems of housing shortage and at the same time to build houses economically by utilizing industrial wastes. The compressive strength, water absorption, density and durability of these bricks and hollow blocks were investigated. It was observed that these bricks and hollow blocks have sufficient strength for their use in low cost housing development [1]. Malhotra S.K and Teri S.P investigated on the development of bricks from granulated blast furnace slag, a 
byproduct of the iron and steel industry. The study revealed that good quality bricks can be produced from a slag-lime mixture and sand by pressing the mix at a pressure of $50 \mathrm{~kg} / \mathrm{cm}^{2}$. Bricks of wet compressive strength in the range of $80-150 \mathrm{~kg} / \mathrm{cm}^{2}$ have been obtained after 28 days of humid curing at ambient temperature. Production of slag based bricks consumes less energy compared to conventional burnt clay bricks or calcium silicate bricks [2].

Ben net Jose Mathew et al. carried out a study on development of geopolymer binder based bricks using fly ash, GGBS and bottom ash. The effect of percentage of binder by weight, percentage of GGBS by weight in total aluminosilicate binder materials, sodium silicate to sodium hydroxide ratio and alkaline liquid to aluminosilicate solid ratio were studied using full factorial design [3].

The main objective of this study is to develop the bricks with manufactured sand instead of clay or river sand or other materials. The bricks were cast with industrial waste materials such as fly ash and GGBS, cement and M-sand. GGBS is used to achieve proper binding between the binders.

\section{EXPERIMENTAL INVESTIGATION}

\subsection{Materials Used}

Materials used in this investigation are Portland Pozzolona Cement (PPC), fly ash, Ground Granulated Blast furnace Slag and M- sand. Portland Pozzolona Cement is a cementations material which is widely used in construction that has the property of binding other materials together. The specific gravity of cement used is 2.95. Fly ash used is Class F Fly ash which has a specific gravity of 1.92 conforming to IS 3812-2003 [4] and GGBS has a specific gravity of 2.80. M-sand which conforms to Grading zone II as per IS: 383:1970 [5] having a specific gravity of 2.3, fineness modulus of 4.2 and bulk density of $1037 \mathrm{~kg} / \mathrm{m}^{3}$ was used. The chemical composition of fly ash and GGBS is given in Table 1 and Table 2 respectively

Table1. Chemical properties of fly ash

\begin{tabular}{|c|c|c|c|}
\hline S. No. & Characteristics & $\begin{array}{c}\text { Requirements as per IS:3812-2003 (\% by } \\
\text { Mass) }\end{array}$ & Test result (\% by Mass) \\
\hline 1 & $\mathrm{SiO}_{2}+\mathrm{Al}_{2} \mathrm{O}_{3}+\mathrm{Fe}_{2} \mathrm{O}_{3}$ & Total $>70.0$ & 88.86 \\
\hline 2 & $\mathrm{SiO}_{2}$ & $>35.0$ & 53.66 \\
\hline 3 & $\mathrm{MgO}$ & $<5.0$ & 2.89 \\
\hline 4 & $\mathrm{SO}_{3}$ & $<5.0$ & 0.35 \\
\hline 5 & $\mathrm{Na}_{2} \mathrm{O}$ & -- & 1.38 \\
\hline 6 & $\begin{array}{c}\text { Loss of ignition } \\
\text { including moisture }\end{array}$ & $<7.0$ & 1.02 \\
\hline
\end{tabular}

Table2. Chemical properties of GGBS

\begin{tabular}{|c|c|c|c|}
\hline SI. No. & Characteristic & $\begin{array}{c}\text { Requirements [6] as per BS:6699 } \\
(\% \text { by Mass })\end{array}$ & Test result (\% by Mass) \\
\hline 1. & Insoluble residue & $<1.5$ & 0.4 \\
\hline 2. & Magnesia content & $<14.0$ & 7.86 \\
\hline 3. & Sulphidesulphur & $<2.0$ & 0.5 \\
\hline 4. & Sulphite content & $<2.5$ & 0.4 \\
\hline 5. & Loss of ignition & $<3.0$ & 0.29 \\
\hline 6. & Maganese content & $<2.0$ & 0.11 \\
\hline 7. & Chloride content & $<0.1$ & 0.008 \\
\hline 8. & Glass & $>67.0$ & 93.0 \\
\hline 9. & Moisture & $<1.0$ & 0.10 \\
\hline 10. & $\mathrm{CaO}+\mathrm{MgO}+\mathrm{SiO}_{2}$ & $>66.66$ & 7.46 \\
\hline
\end{tabular}

\subsection{Mix Proportions}

The mix ratio adopted for manufacturing of bricks is 1:2 (Binder: M-sand)/ the binder consists of fly ash, GGBS and cement. Four different mixes were considered for the present study. The mix ratios adopted are given in Table 3.In all the four mixes, cement content is kept constant. The fly ash and GGBS contents are varied in all the mixes. 
Table3. Mix Ratios for bricks

\begin{tabular}{|c|c|c|c|c|}
\hline Mix ID & GGBS & Fly ash & Cement & M-sand \\
\hline M1 & 0.75 & 0.15 & 0.1 & 2 \\
\hline M2 & 0.6 & 0.3 & 0.1 & 2 \\
\hline M3 & 0.45 & 0.45 & 0.1 & 2 \\
\hline M4 & 0.3 & 0.6 & 0.1 & 2 \\
\hline
\end{tabular}

\subsection{Specimens and Testing}

For this project, totally 100 fly ash bricks of size $190 \mathrm{~mm}$ x $90 \mathrm{~mm}$ x $90 \mathrm{~mm}$ were cast with 25 bricks for each mix. The ingredients fly ash, GGBS, PPC and M-sand were hand mixed and the uniformly mixed ingredients were placed in the brick moulds. Finishing was done by leveling the surface with the trowel. After demoulding process, the bricks were allowed to cure for 7 days and 21 days. The cast bricks are shown in Figure 1. The bricks were then tested for density, dimensional tolerance, compressive strength and water absorption. Density was obtained by dividing the weight of brick by its volume.

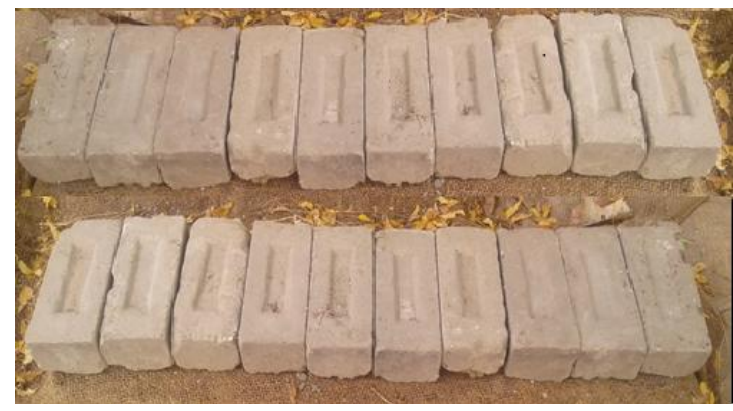

Figure1. Bricks after casting

For dimensional tolerance test, 20 samples were taken and they were arranged upon a level surface successively in contact with each other and also ensuring that they are in a straight line. The overall length, width and height of the assembled bricks were measured using a steel tape to the nearest millimeter. All these dimensions were then added together. This procedure was carried out for bricks prepared from each mix. For compression test, three bricks were taken from each mix and the specimens were placed in the Compression Testing Machine with mortar filled face facing upwards and flat faces horizontal between plates of the testing machine. The load was applied axially at an uniform rate of $14 \mathrm{~N} / \mathrm{mm}^{2}\left(140 \mathrm{~kg} / \mathrm{cm}^{2}\right)$ per minute till failure occurs and maximum load at failure was noted for each of the test samples. The failure load is maximum load at which the specimen fails. For water absorption test, again three samples were taken from each of the mixes and they were dries in a ventilated oven at a temperature of $105^{\circ} \mathrm{C}$ to $115^{\circ} \mathrm{C}$ till it attains substantially constant mass. The specimens were then cooled to room temperature and their weights were obtained. Then the dried specimens were immersed in clean water at a temperature of $27+2^{\circ} \mathrm{C}$ for 24 hours. The specimens were removed and any traces of water were wiped out with damp cloth and once again the specimens were weighed. The water absorption was then calculated from the difference in weights noted before and after immersion [7].

\section{RESULTS AND DISCUSSION}

\subsection{Density}

The Density of fly ash estimated at 21 days is given in Table 4 . From the test results it can be seen that, for bricks containing equal quantities of fly ash and GGBS, the average density falls below 2100 $\mathrm{kg} / \mathrm{m}^{3}$.For all other mixes, density is above $2100 \mathrm{~kg} / \mathrm{m}^{3}$.

Table4. Density of bricks

\begin{tabular}{|c|c|c|c|c|c|}
\hline S.No. & Mix ID & Sample No. & Weight (kg) & Density $\left(\mathrm{kg} / \mathrm{m}^{3}\right)$ & Average Density $\left(\mathrm{kg} / \mathrm{m}^{3}\right)$ \\
\hline \multirow{3}{*}{1.} & \multirow{3}{*}{$\mathrm{M}_{1}$} & 1 & 3.105 & 2017.5 & \multirow{3}{*}{2128.2} \\
\hline & & 2 & 3.308 & 2149.4 & \\
\hline & & 3 & 3.413 & 2217.6 & \\
\hline \multirow{3}{*}{2.} & \multirow{3}{*}{$\mathrm{M}_{2}$} & 1 & 3.310 & 2150.7 & \multirow{3}{*}{2132.3} \\
\hline & & 2 & 3.345 & 2173.5 & \\
\hline & & 3 & 3.190 & 2072.7 & \\
\hline
\end{tabular}




\begin{tabular}{|l|l|l|l|l|l|}
\hline \multirow{3}{*}{3.} & \multirow{3}{*}{$\mathrm{M}_{3}$} & 1 & 2.979 & 1935.6 & \multirow{3}{*}{2015.1} \\
\cline { 3 - 5 } & & 2 & 3.116 & 2024.6 & \\
\cline { 3 - 5 } & \multirow{3}{*}{4.} & 3 & 3.209 & 2085.1 & \multirow{2}{*}{2114.1} \\
\cline { 3 - 5 } & \multirow{3}{*}{$\mathrm{M}_{4}$} & 2 & 3.275 & 2128.0 & 2174.1 \\
\cline { 3 - 5 } & & 3 & 3.346 & 2040.2 & \\
\hline
\end{tabular}

\subsection{Dimensional Tolerance}

The test results of the dimensional tolerance test are given in Table 5. Except M3 which contains equal quantities of fly ash and GGBS, all other bricks satisfy the limits specified in IS 12894: 2002 [8].

Table5. Test results of Dimensional Tolerance test

\begin{tabular}{|c|c|c|c|c|c|c|}
\hline $\begin{array}{c}\text { Dimension in } \\
\text { mm }\end{array}$ & \multicolumn{4}{|c|}{ Mix ID } & \multirow{2}{*}{$\begin{array}{c}\text { Limits as per IS } \\
\mathbf{1 2 8 9 4 : 2 0 0 2}\end{array}$} & \multirow{2}{*}{ Remarks } \\
\cline { 2 - 5 } & M1 & M2 & M3 & M4 & Within limit \\
\hline Length & 3748 & 3740 & 3732 & 3722 & 3720 to $3880 \mathrm{~mm}$ & Not satisfied for M3 \\
\hline Width & 1790 & 1787.4 & 1756 & 1766 & 1760 to $1840 \mathrm{~mm}$ & Within limit \\
\hline Height & 1788 & 1782 & 1778 & 1789.6 & 1760 to $1840 \mathrm{~mm}$ & \\
\hline
\end{tabular}

\subsection{Compressive Strength}

The compressive strength of bricks at 7 and 21 days is shown in Figure 2 for all the four mixes. The minimum average wet compressive strength of fly ash bricks shall not be less than the one specified for each class as mentioned in IS: 12894, when tested as described in IS 3495 - Part 1[9]. The wet compressive strength of any individual brick shall not fall below the minimum average wet compressive strength specified for the corresponding class of bricks by more than 20 percent. From the test results it can be seen that the average compressive strength is higher for mix M1 that contains $75 \%$ fly ash, $15 \%$ GGBS and 10\% PPC, when compared to mixes M2, M3 and M4. The compressive strength of M1 satisfies the minimum compressive strength specified for Class 3.5 designated as per IS12894: 2002. The other mixes do not fall under any of the classes of bricks stipulated in IS 12894: 2002. M1 bricks can be used for framed structures and compound walls.

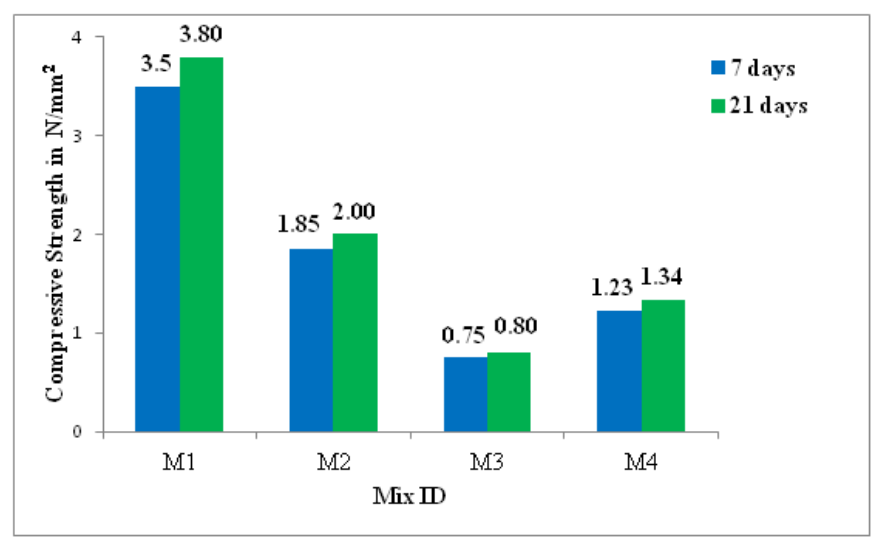

Figure2. Compressive strength

\subsection{Water Absorption}

The values of water absorption for individual bricks and the average values are shown in the Table 6 . The results indicated that M1 [GGBS (75\%), fly ash (15\%), cement (10\%)] has minimum water absorption of $13.08 \%$ and M3 (GGBS (45\%), fly ash (45\%), cement (10\%)] has the maximum water absorption of $16.8 \%$. According to IS 12894: 2002, water absorption should not be more than $20 \%$ by weight up to class 12.5 . For all the mixes, the water absorption is within $20 \%$.

Table 6. Percentage of water absorption

\begin{tabular}{|c|c|c|c|c|c|}
\hline $\begin{array}{c}\text { Mix } \\
\text { ID }\end{array}$ & $\begin{array}{c}\text { Specimen } \\
\text { No. }\end{array}$ & $\begin{array}{c}\text { Weight of dry } \\
\text { specimen in kg }\end{array}$ & $\begin{array}{c}\text { Weight of wet } \\
\text { specimen in kg }\end{array}$ & $\begin{array}{c}\text { Water } \\
\text { absorption in \% }\end{array}$ & $\begin{array}{c}\text { Average water } \\
\text { absorption in \% }\end{array}$ \\
\hline \multirow{3}{*}{1} & 1 & 3.075 & 3.520 & 14.47 & \multirow{2}{*}{13.08} \\
\cline { 2 - 5 } & 2 & 3.056 & 3.488 & 13.13 & \multirow{2}{*}{} \\
\cline { 2 - 5 } & 3 & 3.071 & 3.148 & 13.05 & \\
\hline
\end{tabular}




\begin{tabular}{|c|c|c|c|c|c|}
\hline \multirow{3}{*}{2} & 1 & 2.802 & 3.196 & 14.06 & \multirow{3}{*}{15.95} \\
\hline & 2 & 2.837 & 3.475 & 22.40 & \\
\hline & 3 & 2.908 & 3.251 & 11.40 & \\
\hline \multirow{3}{*}{3} & 1 & 2.678 & 3.240 & 20.90 & \multirow{3}{*}{16.80} \\
\hline & 2 & 2.884 & 3.196 & 13.90 & \\
\hline & 3 & 2.770 & 3.209 & 15.80 & \\
\hline \multirow{3}{*}{4} & 1 & 2.797 & 3.256 & 16.40 & \multirow{3}{*}{14.06} \\
\hline & 2 & 2.862 & 3.284 & 13.60 & \\
\hline & 3 & 2.978 & 3.338 & 12.08 & \\
\hline
\end{tabular}

4. CONCLUSION

Based on the experimental investigations carried out the following conclusions are arrived at:

- For bricks containing equal quantities of fly ash and GGBS, the average density falls below 2100 $\mathrm{kg} / \mathrm{m}^{3}$

- Except bricks which contains equal quantities of fly ash and GGBS, all other bricks passed the dimensional tolerance test

- The compressive strength of bricks containing $75 \%$ GGBS, $15 \%$ fly ash and $10 \%$ PPC satisfies the minimum compressive strength specified for Class 3.5 designated as per IS 12894: 2002. Hence these bricks can be used for framed structures and compound walls. The other mixes do not fall under any of the classes of bricks stipulated in IS 12894: 2002.

- For all the bricks tested, the water absorption is within $20 \%$ which is the limit prescribed as per IS 12894: 2002.

\section{REFERENCES}

[1] Sunil Kumar. (2002), "A perspective study on fly ash-lime-gypsum bricks and hollow blocks for low cost housing development", Construction and Building Materials, 16(8), 519-525.

[2] Malhotra, S. K., and S. P. Tehri. (1996), "Development of bricks from granulated blast furnace slag." Construction and Building Materials, 10(3), 191-193.

[3] Ben net Jose Mathew., Sudhakar M and Natarajan. (2013), "Development of coal ash-GGBS based geopolymer bricks", European International Journal of Science and Technology, 2(3), 133-139.

[4] IS: $3812-2003$ Specification for fly ash for use as Pozzolana And Admixture. Bureau of Indian Standards (BIS), New Delhi.

[5] IS 383 -1970, Specifications for Coarse and Fine Aggregate from natural sources for concrete, Bureau of Indian Standards (BIS), New Delhi.

[6] BS 6699:1992. "Specification for Ground granulated blast furnace slag for use with Portland cement."

[7] IS: 3495 - 1992. Methods of tests of burnt clay building bricks: Part 2 - Determination of water absorption, Bureau of Indian Standards (BIS), New Delhi.

[8] IS: 12894 - 2002. Pulverized fuel ash - lime Bricks -Specification. Bureau of Indian Standards (BIS), New Delhi.

[9] IS: 3495 - 1992. Methods of tests of burnt clay building bricks: Part 1 - Determination of compressive strength, Bureau of Indian Standards (BIS), New Delhi.

\section{AUTHORS' BIOGRAPHY}

Dr. R. Kumutha, is the Professor\& Dean, Department of Civil Engineering, Sethu Institute of Technology. She has authored about 50 papers in various International and National Journals. She has received ISTE Periyar Award for the Best Engineering College Teacher from ISTE, Tamilnadu \& Pondicherry Section for Outstanding Contribution in Technical Education, in December 2016. She has also received a National Award for Innovative research from ISTE, New Delhi in the year 2014.

Dr. K. Vijai, is the PG Program Head, Department of Civil Engineering, Sethu Institute of Technology. He has about 20 years of teaching experience. He has authored about 40 papers in various International and National Journals. He has guided about 25 UG projects and about 15 PG projects. 
S. Noor Nasifa, is the Undergraduate Engineering students of Department of Civil Engineering, Sethu Institute of Technology.

M. Nivedhidha, is the Undergraduate Engineering students of Department of Civil Engineering, Sethu Institute of Technology.

R. Mukila Preethi, is the Undergraduate Engineering students of Department of Civil Engineering, Sethu Institute of Technology.

Citation: R. Kumutha et.al. "Experimental Investigation on Fly Ash Bricks Incorporating M-Sand and GGBS”, International Journal of Constructive Research in Civil Engineering, 4(2), pp.1-6. DOI: http://dx. doi.org/10.20431/2454-8693.0402001

Copyright: (C) 2018 R. Kumutha, This is an open-access article distributed under the terms of the Creative Commons Attribution License, which permits unrestricted use, distribution, and reproduction in any medium, provided the original author and source are credited. 